ANUARIO DE ESTUdios MEDIEVALES

50/1, enero-junio de 2020, pp. 231-266

ISSN 0066-5061

https://doi.org/10.3989/aem.2020.50.1.09

\title{
LA DESAPARECIDA PORTADA ROMÁNICA DEL MONASTERIO DE SANTA MARÍA DE CARRACEDO (LEÓN)*
}

\author{
THE LOST ROMANESQUE PORTAL \\ OF THE MONASTERY OF SANTA MARÍA DE CARRACEDO (LEÓN)
}

\author{
José AlBERTO MORÁIS MORÁN \\ Instituto de Estudios Medievales, Universidad de León \\ https://orcid.org/0000-0002-0069-5864 \\ MARÍA CONCEPCIÓN COSMEN ALONSO \\ Instituto de Estudios Medievales, Universidad de León \\ https://orcid.org/0000-0003-3333-5782
}

\begin{abstract}
Resumen: Esta investigación estudia los vestigios románicos conservados de la desaparecida puerta norte de la iglesia del monasterio de Santa María de Carracedo (El Bierzo, León), en concreto seis capiteles y dos estatuas columna con las efigies del rey Alfonso VII y el abad Florencio, renovadores del cenobio a partir del año 1138. Se analizan y datan dichas esculturas, ubicándolas en el templo y reflexionando sobre sus dimensiones simbólica e iconográfica. Asimismo, se demuestra el patrocinio de la casa real leonesa en esta obra casi perdida y la participación de artífices conocedores de experiencias plásticas internacionales, deudoras de la escultura de la basílica de Saint-Denis de París.

Palabras clave: Carracedo; portada; estatuas-columna; patronazgo; León; Astorga; París.

Abstract: This research deals with the remains from the now lost Romanesque north entrance of the monastic church of Santa Maria de Carracedo (El Bierzo, León), specifically with six capitals and two column-statues depicting King Alfonso VII and Abbot Florencio, true renovators of the friary from the year 1138 onwards. The statues are analysed and dated, as well as located within the church, and their symbolic and iconographic dimensions are considered. The patronage of the Royal House of León in this almost lost work is also demonstrated, together with the participation of artists already familiar with the international sculpture of the basilica of Saint-Denis in Paris.
\end{abstract}

Keywords: Carracedo; entrance; column-statues; patronage; León; Astorga; Paris.

\section{SUMARIO}

1. Los orígenes del monasterio.- 2. La construcción de la iglesia románica a partir de los documentos.- 3. La destrucción del templo y su portada.- 4. Las estatuas-columna del rey Alfonso VII y del abad Florencio.- 5. Los capiteles de la puerta.- 6. El acceso en el marco de la escultura del reino de León a mediados del siglo XII.- 7. La comitencia artística de la corte leonesa.- 8. Dimensión simbólica de la portada.9. Bibliografía citada.

\footnotetext{
"Algunos aspectos preparatorios e iniciales del estudio aquí desarrollado fueron presentados, mediante una comunicación, en el XXI Congreso Nacional de Historia del Arte, celebrado en Burgos en el mes de junio de 2018.

Citation / Cómo citar este artículo: Moráis Morán, José Alberto; Cosmen Alonso, María Concepción (2020), La desaparecida portada románica del monasterio de Santa María de Carracedo (León), "Anuario de Estudios Medievales" 50/1, pp. 231-266. https://doi.org/10.3989/aem.2020.50.1.09

Copyright: (C) 2020 CSIC. Este es un artículo de acceso abierto distribuido bajo los términos de la licencia de uso y distribución Creative Commons Reconocimiento 4.0 Internacional (CC BY 4.0).
} 


\section{LOS ORÍGENES DEL MONASTERIO ${ }^{1}$}

El monasterio de Santa María de Carracedo (El Bierzo,León), antiguo de San Salvador, es el lugar donde se han conservado dos estatuas columna y seis capiteles románicos que serán objeto de este trabajo. Las efigies, que representan a un monarca coronado y a un clérigo con mitra, parecen hacer referencia a dos de los patrocinadores del cenobio y ejemplifican la imagen de los poderes regio y eclesiástico que lo ampararon (fig. 1).



Fig. 1. Restos de la desparecida puerta norte

del monasterio de Santa María de Carracedo (León). Foto: autores.

San Salvador de Carracedo fue una fundación real que, según la tradición y los textos, llevó a cabo Vermudo II (982-989) a finales del siglo X, con el fin de recoger a monjes que habían huido de las zonas asoladas por los musulmanes ${ }^{2}$.

El lugar donde se levantó el monasterio fue un predio real en el que la casa del monarca tenía un palacio ${ }^{3}$, aunque los arqueólogos han dudado de

\footnotetext{
${ }^{1}$ Abreviaturas utilizadas: Regla $=$ Aranguren 2000; Cartulario $=$ Martínez 1997.

${ }^{2}$ Pérez 1952, pp. 344-346, sobre la fundación de Carracedo, véase el apéndice 1, p. 437. Consúltese también: Rodríguez 1995, p. 910.

${ }^{3}$ Morales 1765, pp. 168-170; Llamas 1593; Sandoval 1792, vol. II, pp. 340-341; Yepes 1615, pp. 226-227; Flórez 1762, vol. XVI, pp. 47-48 y pp. 208-210; Prieto 1916, p. 29; Quintana 1968, 1977, 1985. Véanse los estudios más recientes de: Balboa 1997; Cosmen 1989, pp. 277-291; Cavero, 2007; Cosmen, 2012, pp. 61-80. Para los aspectos documentales de este estudio, hemos utilizado la edición del Cartulario.
} 
que dicho solar coincidiese con el centro del coto monástico plenomedieval ${ }^{4}$. Dicha fundación pronto decayó y a principios del siglo XII estaba poco activa $^{5}$, a pesar de pertenecer al infantado que regentaba, como indica un documento de 1130, la infanta Sancha Raimúndez (1095-1159), hermana del rey Alfonso VII (1126-1157), e hija de Raimundo de Borgoña y Urraca de León ${ }^{6}$.

Aunque no lo pormenorizan los textos, la dama pensó en revitalizarlo y vincularlo a la estricta observancia de San Benito. Esta idea se deduce del documento de refundación de 1138, donde además de pedir al abad Florencio y sus monjes, procedentes de San María de Valverde (lugar cercano al vecino Corullón), que se encarguen de la restauración del lugar, se dice expresamente que la empresa se dedicará a Santa María, otorgándola libre y exenta de la potestad regia y de cualquier yugo de servidumbre, además de informar que aún allí estaba enterrado Vermundo II a die edificatum est a domino Beremundo rege, qui in eo sepultus est, usque in diem hanc. Finalmente, la fuente indica que se tenga como cabeza de todos los cenobios que hubiese sujetos a él $7^{7}$.

Resulta significativo que en el templo de Corullón existiese una inscripción -hoy perdida- que se ubicaba en la puerta lateral, y hacia memoria de la consagración realizada en 1112 por el obispo de Astorga Pelayo (10981121). En ella se mencionaban a San Salvador ligno Domini, San Miguel, Santa Marina y Santa María ${ }^{8}$, advocaciones tradicionales que el monasterio reformado de Carracedo tomará como propias.

Por otra lado, la situación que promueve la infanta Sancha en 1138 se ve refrendada por el papa Inocencio II (1130-1143), en abril de 1139, cuando confirma al abad Florencio las posesiones de San Salvador de Carracedo bajo la regla de San Benito y la dependencia del obispo de Astorga9 .

\footnotetext{
${ }^{4}$ Miguel 1996, pp. 131-162.

${ }^{5}$ Aún el 29 de junio de 1003 se cita en los límites de una heredad vendida por unos particulares, en Cigüeñuela, territorio de León, que limitaba con "Karrazeto et suo monte": Ruiz 1987, vol. III, doc. 634, p. 170.

${ }^{6}$ Cartulario, doc. 15 , p. 246. Para la bibliografía más reciente sobre la infanta véase Cavero 2013, pp. 271-297.

${ }^{7}$ Cartulario, doc. 16, p. 36 y Martín 2003, doc. 24, p. 257. La federación de monasterios dependientes de Carracedo se expandió por Galicia, Asturias, Zamora y el entorno berciano. $C f$. Cavero 2013, p. 294. Agradecemos al Dr. Santiago Domínguez su ayuda en las cuestiones relativas al latín.

${ }^{8}$ Llamas 1593.

${ }_{9}^{9}$ Cartulario, doc. 19, p. 39; Quintana 1985, pp. 201-224. El obispo de Astorga entre 1138 y 1141 fue Jimeno Eriz.
} 


\section{LA CONSTRUCCIÓN DE LA IGLESIA ROMÁNICA \\ A PARTIR DE LOS DOCUMENTOS}

En 1138 el monasterio empezó la construcción y dotación de nuevos espacios. Las noticias artísticas son escasísimas, pero ya en 1140 se habla de libros de altar y vestimentas para los monjes, en una donación hecha a Florencio, al cenobio y a su basílica de San Salvador, por el siervo Sancius Gundisalviz ${ }^{10}$.

En esta etapa de gastos e inversiones la infanta Sancha, en 1142, sigue dando su apoyo al monasterio, pues les traspasa todo lo que posee en Cacabelos de realengo e infantado ${ }^{11}$. Ese mismo año, otro monje destacado del monasterio, Pedro Cristiano, le dona todo lo que le correspondía de la herencia familiar tras el reparto con sus hermanos. En el futuro dicho personaje llegará a ser obispo asturicense, entre 1153 y 1156, y antes fue el encargado de revitalizar el monasterio de San Martín de Castañeda (Zamora) a partir de $1150^{12}$.

Esta campaña de apoyo de la nobleza continúa en 1143, con donaciones de la infanta y de particulares ${ }^{13}$, dádivas que afianzaron la reorganización del enclave y posibilitaron las mejoras que en él se estaban llevando a cabo, quizás con la cabecera del templo monástico ya planteada o en construcción.

Sin más noticias conservadas, llegamos al 2 de febrero 1152, cuando el rey Alfonso VII dona a Santa María de Carracedo otra propiedad, en el lugar de Villaturriu, cerca de Carrión, mientras que la condesa doña Loba les concede propiedades en Penín y Buscale ${ }^{14}$. Desde este momento la advocación en los documentos que conocemos va a ser siempre Santa María y nunca más San Salvador. Es posible que la cabecera del nuevo templo se hubiese consagrado a la Virgen, como señaló desde 1138 su promotora y que, quizás, las obras estuviesen planteadas hasta el crucero.

La documentación refleja la fortaleza de Carracedo a mediados del siglo XII, pues el 28 de agosto de 1152 la infanta encarga al abad Florencio la refundación de un monasterio femenino en San Miguel de Almázcara ${ }^{15}$.

Posiblemente la cabecera del edificio debía estar construida a la muerte del abad Florencio a finales de 1152. El sucesor fue el abad Diego Peláez, de mandato breve, pues muere en diciembre de $1155^{16}$. De este corto

${ }^{10}$ Cartulario, doc. 20, p. 40, dado el 25 de junio.

${ }^{11}$ Cartulario, doc. 23, p. 43; Martín 2003, doc. 32, p. 267.

${ }^{12}$ Cartulario, doc. 24, p. 43; Quintana 1985, pp. 303-358.

${ }^{13}$ Donación de la iglesia de San Martín, cerca de Rioseco (León), de una heredad en el barrio de Camba (Galicia) y animales de carga y cereal para el mantenimiento de los monjes. Cf. Cartulario, docs. 25 y 26, p. 44; Martín 2003, doc. 36, p. 271; Fernández 1990, doc. 1438, p. 210.

${ }^{14}$ Cartulario, docs. 30-31, p. 47; Martín 2003, p. 170.

${ }^{15}$ Ibidem, pp. 301-302; Cavero 1994, doc. 152, p. 55.

${ }^{16}$ García 1997, pp. 189-206. 
periodo tenemos escasas noticias, pero significativas, pues el monasterio comienza a negociar con sus propiedades y el monarca le otorga otra donación ${ }^{17}$, a pesar del contexto conflictivo con Santa María de Toldanos ${ }^{18}$.

Finalmente, entre 1158 y 1186 Carracedo fue regido por el abad Gualterio, un largo periodo de 28 años en el que la documentación silencia noticias de cariz artístico ${ }^{19}$. No obstante, los diplomas conservados dejan traslucir el afianzamiento del cenobio por medio de compras, cambios y donaciones que se realizan en esos años. Transacciones que, mayoritariamente, se hacen en tierras bercianas pero sin descuidar las zonas gallegas y la Tierra de León $^{20}$. No existe entre la documentación venta alguna de los bienes del monasterio durante su abadiazgo, solo adquisiciones y algún alquiler, reflejo de la acumulación de patrimonio destinado a la fábrica.

Cuando Gualterio se hizo cargo del monasterio tenía aún como valedora a la infanta Sancha pero ella pronto murió, en febrero de 1159. No obstante, el nuevo rey de León, Fernando II (1157-1188), no desamparó la institución, pues el 27 de marzo de ese año, estando en Villafranca del Bierzo, camino de Galicia, confirmó las heredades que su padre había dado a Carracedo, en un documento que también ratifica el obispo astorgano Fernando el Vétulo (1156-1172) ${ }^{21}$. Ello indica que las relaciones con el obispado no eran problemáticas pero pronto se hicieron más tensas, especialmente en 1163, cuando el prelado consigue del papa Alejandro III (1159-1181) una bula de advertencia a los cluniacenses que actúen contra el obispo asturicense.

Los asuntos de Carracedo, con el problema de Toldanos aún vigente, se van resolviendo con la intervención del cardenal legado Jacinto que, además, en 1172, consiguió que la Santa Sede tomase bajo su protección al monasterio berciano ${ }^{22}$.

\footnotetext{
${ }^{17}$ Cartulario, docs. 37 y 39 , pp. 51-52. El documento primero se refiere a un matrimonio que vende al monasterio propiedades en "Villaferrarios". En el segundo, el monarca da al monasterio la villa de Fervenza de Camba, en el concejo pontevedrés de Rodeiro.

${ }^{18}$ Se trata de un monasterio de la confederación carrecetense que se desvinculó de esta en 1152, intentando el amparo del monasterio de Claraval. Ello dio pie a la célebre carta entre la infanta Sancha y San Bernardo. Aún se debate sobre su emplazamiento, entre las cercanías de Puente Villarente y Villaturiel (León), cerca de Valderas (León) (Cartulario, p. XVI), cerca de Villalón de Campos (Valladolid) (Quintana 1983, vol. II, p. 337) o Cañizo de Campos (Zamora): García 1972, anexo V, p. 179; Cavero 2013, pp. 295-296; Alonso 2007, p. 685.

${ }^{19}$ Gualterio fue prior de la comunidad al menos desde el año 1155 , cuando muere el abad Diego. Cf. Cartulario, doc. 56, p. 63.

${ }^{20}$ Cartulario, docs. 43, 71, 75 y 90, pp. 54, 75, 79, 89; González 1943, p. 442.

${ }^{21}$ Llamas 1593, p. 86; Quintana 1985, p. 377.

${ }^{22}$ Cartulario, doc. 57, p. 66; Quintana 1985, pp. 427-430. Aunque el edificio ya aparece siempre en la documentación como Santa María, el documento especifica que la regla seguida era la benedictina.
} 
El amparo del papado se documenta aún en 1183 cuando Lucio III (1181-1185) otorgó varias bulas facultando al monasterio para visitar y corregir a sus filiales, eximiéndolo de gabelas y confirmando sus posesiones ${ }^{23}$. Es decir, el abad contaba tanto con el apoyo papal como con el del rey, que lo consideraba venerabile e dilectissimo nostro ${ }^{24}$.

Otro dato existente al final del abadiato de Gualterio, que muere en 1186, nos parece relevante. Un documento indica la intervención del rey en el Bierzo para resolver el asunto de la repoblación de Castro Ventosa, desistiendo de tal empeño y favoreciendo al abad con la petram ex eo in Carrazetum usque ad minimam deportari ${ }^{25}$. Nuevamente todo revela que se están acumulando patrimonio y materiales pétreos para sufragar los gastos en la obra, que debía encarar por entonces su fase final, quizás en los dos últimos tramos del buque del templo y el imafronte occidental.

Este enmarque histórico puede ayudar a diferenciar las etapas de construcción del templo monástico del que proceden las esculturas objeto de estudio.

\section{LA DESTRUCCIÓN DEL TEMPLO Y SU PORTADA}

Sabemos que el 8 de julio de 1796 se inició el derrumbe de la cabecera para sustituir la iglesia románica por un edificio neoclásico, dadas las continuadas quejas de la comunidad debido a lo angosto del altar ${ }^{26}$. Cuando Jovellanos (†1811) visitó el enclave a finales del siglo XVIII, llegó a verlo intacto, indicando iglesia larguísima, estrechísima (...) altísima ${ }^{27}$, y la comparó con la del monasterio de Valdediós (Asturias), que posee cinco tramos.

Lamentablemente el área de la cabecera no fue excavada durante las intervenciones arqueológicas realizadas por Fernando Miguel, pero ya Manuel Gómez-Moreno señaló, en 1925, que la planta podía adscribirse a un modelo tradicional de tres ábsides orientados, crucero no marcado, tres naves

\footnotetext{
${ }^{23}$ Cartulario, docs. 86,87 y 88, p. 85 y p. 88 .

${ }^{24}$ Cartulario, doc. 70, p. 75; González 1943, p. 456. Otro factor que quizás alejó al obispado del monasterio berciano atañe al caso del lago de Carucedo, que en 1174 había sido entregado a la iglesia de Astorga y a su obispo Arnaldo (1173-1177) y que cuatro años después el rey Fernando II lo dio a Carracedo, confirmándose el apoyo real. Véase Quintana 1985, p. 478.

${ }^{25}$ Cartulario, doc. 96, p. 93; Quintana 1985, p. 520. El abad Llamas aporta datos sobre la piedra indicando "y no poca se trajo y gastó en el cuerpo de la iglesia": Llamas 1593,p.94. Por su parte Miguel 1996, p. 151, señala que las cuarcitas de Castro Ventosa fueron utilizadas sólo como material de relleno.

${ }^{26}$ González 1990, pp. 211-218.

${ }^{27}$ Blanco, Díaz-Jiménez 1989, p. 86.
} 
y cinco tramos rematados en el imafronte por una torre circular en la ángulo noroccidental, aún conservada hoy (fig. 2$)^{28}$.

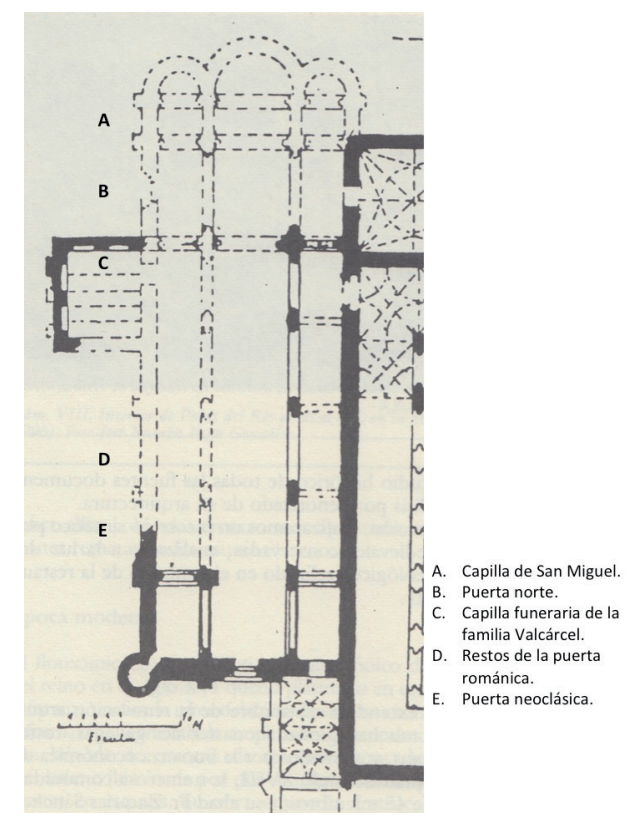

Fig. 2. Planta del monasterio de San Salvador de Carracedo. Foto: Manuel Gómez-Moreno.

Por nuestra parte consideramos que la planta de la iglesia estaba bien definida desde que se colocó la primera piedra en $1138^{29}$ y que, a pesar de que

\footnotetext{
${ }^{28}$ Hoy tan sólo restan en pie los muros meridional, occidental y parte del septentrional en los dos últimos tramos de los pies. A partir de ahí, en ese lado norte, se ubicó la puerta de acceso al templo neoclásico. Estos restos han permitido reconocer los cinco tramos de división de naves, el arco sur de acceso al crucero y los arcos diafragma que apeaban las cubiertas de madera. Que el edificio tuvo este tipo de cubrición lo asegura Llamas en una noticia muy poco valorada donde informa sobre las "soleras de la techumbre de palnudillo de la tercera nave de la iglesia, en la pared aquilonar": Llamas 1593, p. 132; Gómez-Moreno 1925, vol. I, pp. 407-408; Miguel 1996, p. 146.

${ }^{29}$ Llamas señala que, en la primera hoja de una Regla de San Benito "que se leía en el monasterio" existía una nota que refería la colocación de la primera piedra el 15 de octubre de ese año, puesta en presencia del rey Alfonso VII y el abad Florencio (Llamas 1593, p. 67). También recogió la noticia Yepes 1615 , p. 226. La documentación revela que el rey realizó un viaje a través del Bierzo para estar en diciembre en Compostela, pero en octubre se hallaba en Burgos y Carrión y en noviembre en Segovia. Es posible que la fecha exacta de colocación de la primera piedra deba reconsiderarse, aunque como ya se ha explicado el monarca refrendó documentalmente la edificación del monasterio. $C f$. Recuero 1979, pp. 215-216; 1998, docs. 79, 80, 81.
} 
el grueso de los trabajos (crucero, perímetro, cierre de las naves e imafronte) fueron realizados por Gualterio ${ }^{30}$, la unicidad del conjunto, la existencia de un transepto no marcado en planta con sus accesos, así como el uso de torre circular a los pies posee paralelos en edificios tempranos de ese entorno benedictino, como San Isidoro de Dueñas.

Hay varios argumentos que confirman la existencia de una puerta de entrada desde el área norte exterior del recinto monástico, ubicada en un lugar próximo a la cabecera. En primer lugar, situado enfrente de este vano de laicos, debió existir otro, hoy rehecho, que en paralelo, permitía el paso a las dependencias monásticas ubicadas al sur. Por lo tanto estaríamos ante un esquema de composición arquitectónica propia de los templos benedictinos leoneses de la primera mitad del siglo XII.

Por otra parte, la desaparecida puerta no pudo ubicarse en el tramo inmediato al crucero, pues en el siglo XIV se adosó a ese muro una capilla funeraria sufragada por la familia Valcárcel ${ }^{31}$. De haberse situado el vano en ese paño de muro, éste habría sido movido ya en esa centuria.

Sin embargo, está perfectamente documentado que, tras iniciarse el derrumbe de la cabecera románica y con el inicio de la obra neoclásica, se acometió un cuidadoso traslado de las estatuas-columna, junto con seis capiteles y otros materiales pétreos, que analizaremos en las siguientes páginas. Se ubicaron sobre el muro que antecede, hacia oriente, a la puerta septentrional del templo neoclásico y se acompañaron de una inscripción que conmemora la acción, no sin cierta dimensión simbólica: EFFIGIES S. FLORENTII ABBATIS ET ALFONSI IMPERATORIS, QUAE AD PRINCIPALIS VETERIS ECCLESIAE PORTAM COLLOCATAE ERANT ${ }^{32}$.

Otro argumento posibilita ubicar estas esculturas en el transepto del derruido edificio y no en el área del tercer tramo de la iglesia, hacia los pies. Este último espacio acogió durante el siglo XIV una acumulación de elementos que no hubieran hecho funcional ese acceso. Llamas alude a la existencia de una hornacina de enterramiento en el muro, donde después se puso un altar dedicado

\footnotetext{
${ }^{30}$ Las obras en la cabecera avanzaron durante los 14 años del abadiato de Florencio pero, los 28 años del mandato de Gualterio ofrecen un marco amplio para atribuirle el grueso de los trabajos. Los argumentos respaldados por la documentación analizada lo confirman. Por otra parte, ello concuerda con la lectura arqueológica, que reveló la existencia de una campaña, segunda, según Fernando Miguel, que abarcaría el cuerpo del edificio hasta el cierre occidental. A ello ha de sumarse la inscripción de Gualterio - ubicada en la cara norte del contrafuerte de la fachada occidental-, considerada como una intitulatio del propio abad o de algún artífice. Véase García 1996, p. 66; 1997, p. 202. p. 133.

${ }^{31}$ Fue erigida por García Rodríguez de Valcárcel II, muerto en 1328. Cf. Llamas 1593,

${ }^{32}$ Quadrado 1855, p. 445, nota 1; García 1997, pp. 204-205.
} 
a la Santa $\mathrm{Cruz}^{33}$. Sabemos además que un nieto de Valcárcel II se enterró junto a la boca de la capilla de San Miguel ${ }^{34}$, es decir, cerca del arco de triunfo del ábside norte de la cabecera. Todo ello indica la relevancia del área septentrional del crucero, con enterramientos privilegiados a ambos lados, flanqueando la puerta. Se marca así la entrada como espacio codiciado de sepultura y es posible que el lugar fuese objeto de liturgia penitencial y pascual que repercutiera en los finados allí instalados. Sin embargo, su desmembramiento y las escasas noticias conservadas no permiten concretar más su posible ubicación.

El padre Llamas menciona esta portada principal, que le parece que es bien una escultura abominable, especificando que la figura del Emperador está a la mano izquierda y la del abad Florencio a la derecha con su bácu$l o^{35}$. Se trata de noticias nunca valoradas en los estudios que permiten ahora reconstruir la morfología de este conjunto escultórico desaparecido (fig. 3).

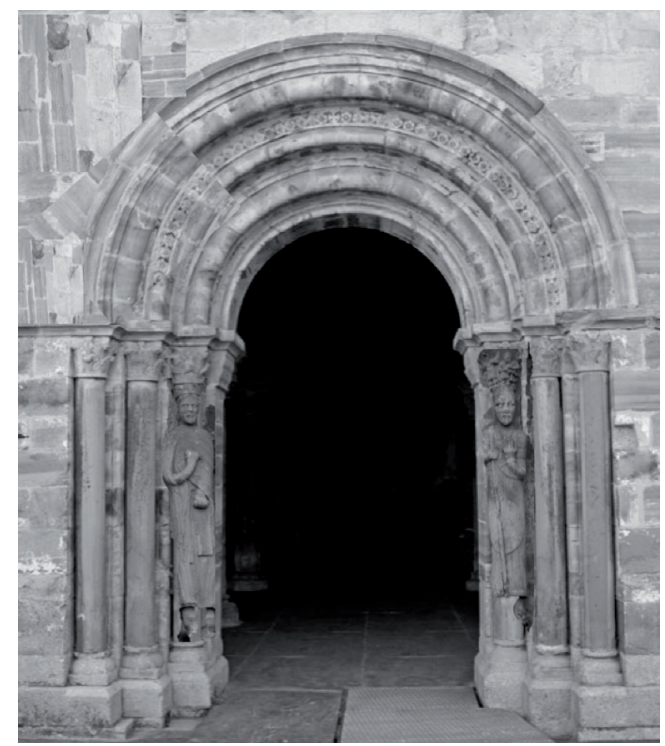

Fig. 3. Reconstrucción de la puerta norte

del monasterio de Santa María de Carracedo (León). Foto: autores.

\footnotetext{
${ }^{33}$ Obra de García Rodríguez de Valcárcel I, muerto en 1308. Cf. Llamas 1593, pp. 131-132.

${ }^{34}$ Este enterramiento se refiere al del biznieto de García Rodríguez Valcárcel I. La fuente indica que "está enterrado junto a la boca de la capilla de San Miguel, en un lucillo de piedra, con su mujer, sobre unos leones", enterramiento que permaneció en ese lugar hasta 1583, pues los monjes decidieron limpiar aquella nave que "había sido tomada tiránicamente siendo la iglesia de patronazgo real": Llamas 1593, pp. 130-133.

${ }^{35}$ Ibidem, p. 74.
} 
También Jovellanos vio la portada en pie. Indicó que era de tipo asturiano $^{36}$ con dos estatuas columna que identificó con el rey, pero dudó sobre la del abad, del que pensaba podía ser el obispo que consagró la iglesia.

Más importante nos parece el testimonio de José María Quadrado, quién indica:

Componíase la portada de tres arcos decrecientes y de seis columnas, dos de ellas como las de la Cámara Santa de Oviedo ocultas tras de las efigies, a las cuales sirven ahora de escabel los capiteles de las restantes. Dichas estatuas nada menos representan al emperador Alfonso y al santo abad Florencio ${ }^{37}$.

En los años cincuenta del siglo XIX, Valentín Carderera escribió que se trataba de esculturas de un arte atrasado, que por su rigidez comparó con momias fajadas y ya en los primeros años del siglo XX, Manuel Gómez-Moreno reconoció, sin dudarlo, al rey y al abad en estas figuras, englobándolas en un arte atrasadísimo aunque libre de prejuicios de escuela, recordando algo las imágenes de la puerta lateral de San Vicente de Ávila ${ }^{38}$.

\section{LAS ESTATUAS-COLUMNA DEL REY ALFONSO VII Y EL ABAD FLORENCIO}

Los testimonios aportados confirman que, efectivamente, la portada contó con tres arquivoltas abocinadas, que volteaban sobres seis capiteles, tres a cada lado, y que hoy forman parte del conjunto empotrado en el muro neoclásico. La fachada tuvo seis columnas acodilladas, dos de ellas con las efigies del rey y del abad, que alcanzan $1,78 \mathrm{~m}$ de altura. El resto eran de fuste liso, pues Jovellanos sólo habla de dos figuras. Es muy importante que ninguno de los autores que la vieron en pie y los que posteriormente aludieron a ella, jamás mencionen la presencia de un tímpano, por lo que pensamos que nunca lo tuvo.

\footnotetext{
${ }^{36}$ Jovellanos 1915, pp. 69-70.

${ }^{37}$ Quadrado 1855, p. 444. El testimonio de Quadrado nos parece preciso. La portada debió tener tres arquivoltas que apeaban en seis columnas con seis capiteles. Aunque un análisis a través de fotografías poco definidas pudiera llevar a pensar al investigador que el conjunto de capiteles sobre los que apenan hoy los pies de las estatuas-columna son piezas dobles de collarino tangente, el análisis pormenorizado que hemos efectuado durante el trabajo de campo, nos permite asegurar que se trata de cuatro capiteles independientes unidos modernamente con mortero.

${ }^{38}$ Carderera 1855-1864, vol. 1, sin paginar, y Gómez-Moreno 1925, p. 413.
} 
La imagen del rey porta una corona ornada en su base inferior con un zigzag a modo de diadema, mientras que la parte superior remata en una primera fila de hojas alancetadas, sobre la que resaltan otras que se vuelven en forma de voluta. La corona es de gran originalidad, escapando de las formas encastilladas tradicionales ${ }^{39}$ (fig. 4).



Fig. 4. Efigie del rey Alfonso VII,

monasterio de Santa María de Carracedo (León). Foto: autores.

Posee cabellera peinada al medio, con mechones que se extienden sobre el fuste rizándose a los lados, dejando ver las orejas. Aparece ligeramente ceñudo, los arcos supraciliares en relieve marcados, párpados abultados, pupilas y barba trabajada en mechones ensortijados en los extremos. La boca, sin expresión, la enmarca un bigote cuyas crenchas se unen con la barba. Con cierta rigidez, la cabeza se une al tronco, que está vestido con una túnica

\footnotetext{
${ }^{39}$ Una solución parecida se encuentra en la imagen del rey sedente de la puerta meridional de San Vicente de Ávila. También el privilegio al monasterio de Santa María la Real (San Martín de Valdeiglesias, Madrid), de 1148, muestra al rey Alfonso VII con una diadema con perlado y zigzag rematada en las esquinas del tocado con tres florones. Los herederos aparecen en la parte izquierda de la miniatura con similares coronas. $C f$. O'Neill 2017, pp. 128-129, con varias erratas en las datas.
} 
cuyo cuello se ajusta con un nudo, mientras el manto se sujeta con una fíbula romboidal ornada con cabujones. Los textiles se ciñen mucho al cuerpo, gestando pliegues poco abultados. La túnica se ajusta mediante un cíngulo anudado cuyos extremos caen por debajo de las rodillas. El manto remata con un orfrés decorado con retícula.

Los brazos, que se adosan al cuerpo, se ocultan bajo el manto, otorgando a la figura una rotundidad en forma de bloque. El izquierdo se gira de forma antinatural para situar la mano cerrada sobre el pecho, sujetando un cilindro, mientras que con la otra despliega un pergamino a modo de filacteria ${ }^{40}$.

El remate inferior de la túnica, rígido y con una leve ondulación, se ciñe a las extremidades otorgando a la imagen verticalidad. Los pies calzados apoyan sobre una peana, muy deteriorada, pero que pudo estar figurada.

El abad, de idéntica medida, posee una mitra baja, con forma triangular en el frente y con motivos geométricos incisos. El cabello se adapta como una banda al cráneo. El rostro es hierático y frontal con ojos almendrados enmarcados por unos párpados abultados que se ocultan en la parte alta bajo unos arcos supraciliares profundamente tallados (fig. 5).

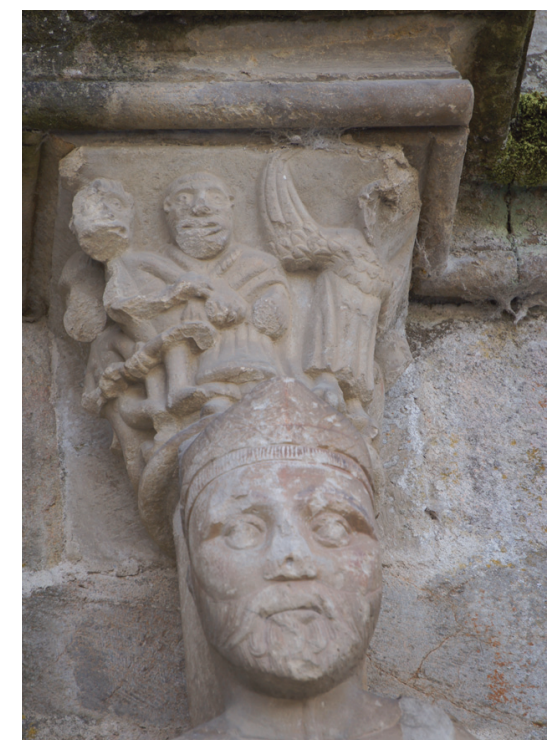

Fig. 5. Efigie del abad Florencio,

monasterio de Santa María de Carracedo (León). Foto: autores.

\footnotetext{
${ }^{40}$ Varios autores de los siglos XVIII y XIX indican que la filacteria es el documento de refundación del monasterio de 1138 .
} 
La línea de la barba remarca, desde abajo, el volumen de las mejillas. La boca vuelve a expresar cierto naturalismo contenido y los mechones de barba y bigote se entrelazan dando lugar a terminaciones acaracoladas. Se trata de un trabajo de cierta calidad, a pesar del desgaste sufrido al estar a la intemperie durante siglos, visible en la fina cinta que sujeta la mitra y que cae desde el cuello por debajo de la barba, extendiéndose a lo largo de pecho. Los remates del orfrés de las vestimentas talares continuarían con la decoración en retícula muy fina.

El abad viste con hábito y una casulla, cuyas mangas rematan con amplitud. Porta guantes y coloca la mano derecha sobre el pecho, extendiendo tres dedos, en una forma de bendición poco canónica. Con la mano izquierda sujeta un báculo de extremos deteriorados ${ }^{41}$. Como en el caso anterior, la figura va calzada y apoya sus pies sobre una base antaño esculpida (fig. 1).

\section{LOS CAPITELES DE LA PUERTA}

Junto a las estatuas se conservan seis capiteles de $30 \mathrm{~cm}$. de altura, dos de ellos apeados sobre las cabezas de las efigies y los restantes, en parejas, les sirven de base. Quadrado indicó que estas piezas formaron parte, como las figuras, de la desparecida portada. En su estado actual, tras empotrarse en el muro neoclásico, se identifican los siguientes motivos, que describimos al no estar analizados hasta la fecha:

El capitel 1 posee figuración, de relieve considerable, en las tres caras visibles de la cesta. En el centro aparece un hombre tonsurado, cubierto con hábito monacal y con una soga al cuello. A la altura de su pecho pende una bolsa, hoy muy perdida. Como indicaremos luego, consideramos que se trata de la representación del pecado de la avaricia (fig. 6).

\footnotetext{
${ }^{41}$ Parcerisa dibujó esta escultura, dando idea del remate superior en forma de esfera, ya por entonces deteriorada. Dada la tendencia cúbica de la efigie, descartamos que el artífice hubiera desarrollado una voluta del báculo exenta del cuerpo, como la que porta el abad del documento de Valdeiglesias. En cuanto al remate inferior, es factible que para poder tallarlo sin peligro de ruptura, se dejara entre los pies del prelado un soporte cilíndrico sobre el que reposaría el tope, a veces de madera o metálico y que en el documento de Valdeiglesias aparece anclado con un clavo al fuste del báculo.
} 


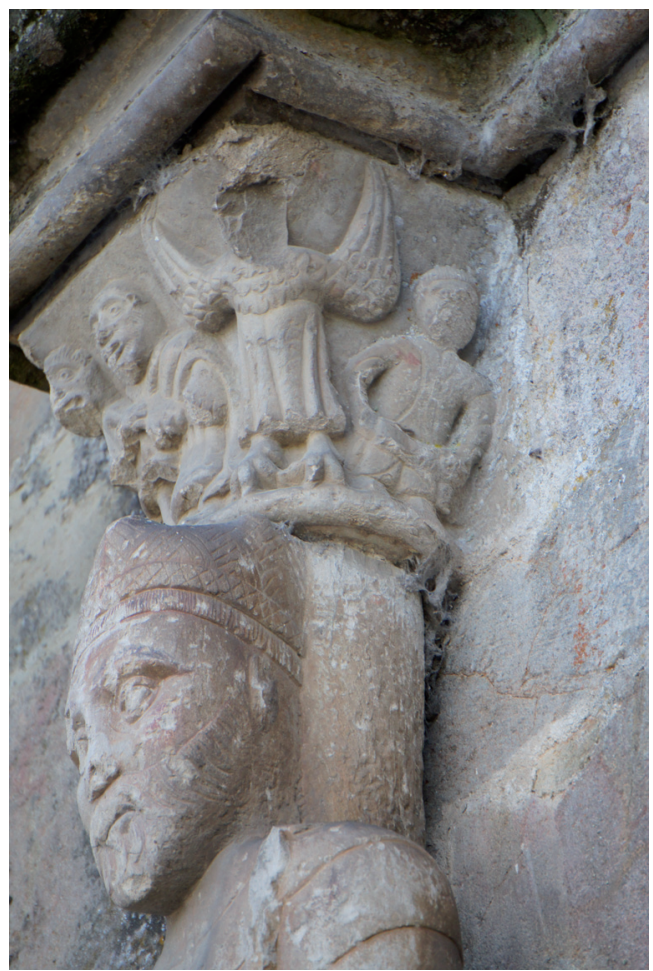

Fig. 6. Capitel del avaro, monasterio de Santa María de Carracedo (León). Foto: autores.

A la izquierda se talló una figura desnuda de rostro demoníaco, tras la cual aparece otra similar. Ambas portan dos horquillas con las que amenazan al clérigo. A la derecha, ocupando la esquina de la cesta, surge una figura con las alas desplegadas. El rostro hoy está perdido, pero presenta garras de ave y torso cubierto de plumas, del que desciende una saya plegada. Se trata de un ser fantástico, amenazante, acompañado por un humano de rasgos clericales en su vestimenta y peinado, en el extremo derecho del capitel. 


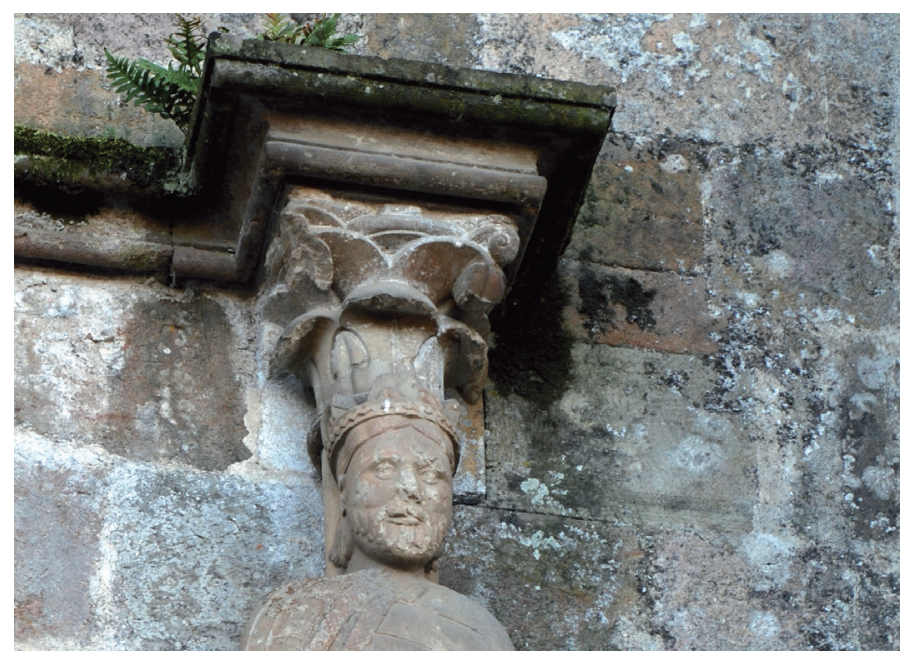

Fig. 7. Capitel vegetal, monasterio de Santa María de Carracedo (León). Foto: autores.

El capitel 2 es vegetal y se ornó con dos bandas de hojas gruesas (fig. 7). La fila inferior presenta rebordes sobresalientes y la superior hojas menos desarrolladas cuyos extremos acogen apomados. El capitel 3 muestra un felino, en la esquina izquierda de la cesta, atacando con sus zarpas a un personaje que yace por tierra mientras, otra figura, en la esquina opuesta, desenvaina su espada. La cola del animal posee un remate apiñado (fig. 8). El capitel 4 presenta dos cuadrúpedos con cabeza humana, posiblemente femenina, que apoyan sus extremidades sobre el astrágalo y dejan ver un fondo vegetal de hojas alancetadas, bajo un remate superior festoneado (fig. 9). En el capitel 5 se talló un cuadrúpedo, en la parte inferior, rodeado de elementos vegetales donde vástagos ondulantes rematan en triples hojas de nervios marcados igual que el zarcillo que lo soporta (fig. 10). 


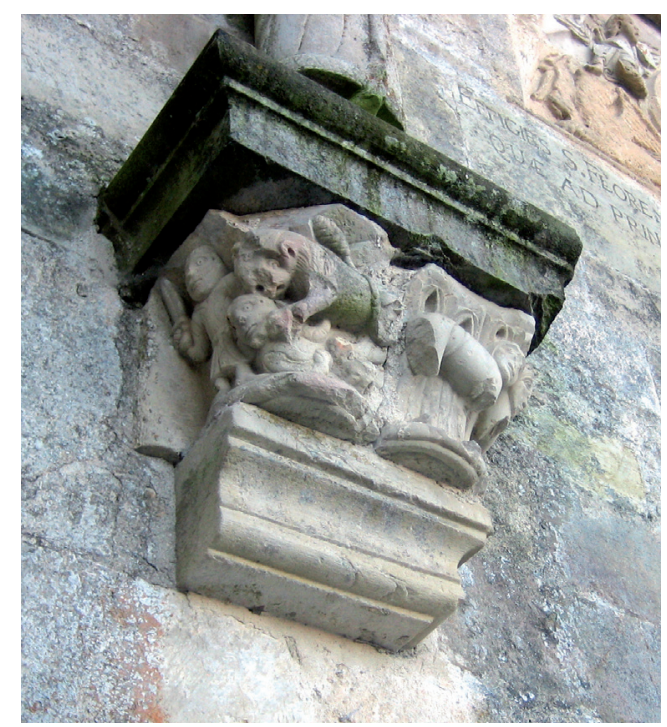

Fig. 8. Capitel con felino y hombre,

monasterio de Santa María de Carracedo (León). Foto: autores.

El último capitel, el número 6, acoge la Epifanía (fig. 11). Los Tres Magos ocupan la cara externa más la esquina del capitel y sus rostros están deteriorados. En la otra superficie visible se ubica la Virgen y el niño. Los Reyes llevan grandes coronas y sus cuerpos se inclinan hacia el Salvador, cubriéndose con ropajes muy plegados y enriquecidos con algún orfrés geométrico. El astrágalo posee una decoración de pequeños boceles superpuestos.

Si la descripción que nos legó Quadrado es cierta y atendiendo a la forma en que están tallados, podemos reubicar estos seis capiteles en el lugar que debieron ocupar originalmente. Así, respetando las caras de las cestas dejadas para empotrarse, concluimos que, en la parte izquierda de la portada, ocupada por el rey con un capitel vegetal sobre la cabeza, se encontraban la Epifanía y los cuadrúpedos con cabeza femenina, que identificamos como mantícoras. En el lado derecho, donde sobre uno de los fustes, estaba la figura del abad, además del capitel del avaro se situarían las piezas con el león y las dos figuras humanas, junto a la del cuadrúpedo con motivos vegetales ${ }^{42}$.

\footnotetext{
${ }^{42}$ Es posible que parte de las líneas de imposta de la puerta estén hoy reutilizadas entre estos restos. Nos referimos a las piezas que enmarcan las dos parejas de capiteles situadas bajo las estatuas columna. Se trata de una solución común en el románico de la diócesis de Astorga. Véase Cosmen 1989, pp. 277-291. Por otra parte, en este tramo de muro neoclásico hemos detectado algunos sillares reutilizados que pudieron proceder del edificio románico. Estos presentan ciertas marcas de cantero que podrían conectarse con la primera fase de la obra y no a
} 


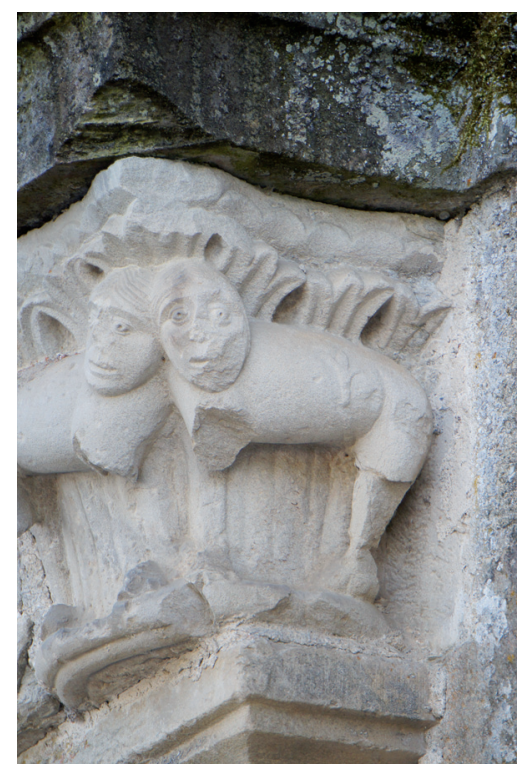

Fig. 9. Capitel con mantícoras,

monasterio de Santa María de Carracedo (León). Foto: autores.

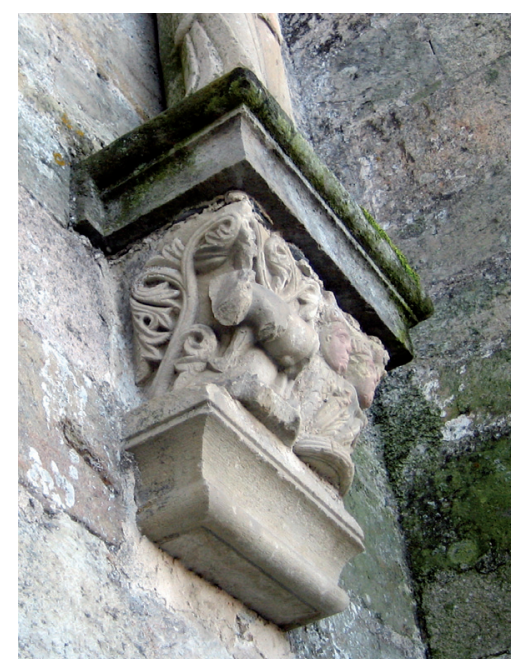

Fig. 10. Capitel con cuadrúpedo y vegetales, monasterio de Santa María de Carracedo (León). Foto: autores.

los trabajos realizados en el cuerpo y pies del edificio. Ello ratificaría que estas piezas proceden de los primeros tiempos de la fábrica, a mediados del siglo XII. 
Actualmente entre las estatuas columna se halla un tímpano que posee la imagen de Cristo en Majestad en mandorla, rodeado del tetramorfos, pieza desconcertarte (...) suplantación de principios del XVI ${ }^{43}$ (fig. 1). Es importante remarcar que las noticias y descripciones más antiguas que poseemos de la puerta, no citan jamás este tímpano como componente de la misma ${ }^{44}$. Tampoco lo tiene la otra puerta románica que hoy conservamos, y que comunicó con el claustro. Todo ello nos lleva a creer que la portada que analizamos no lo tuvo.



Fig. 11. Capitel de la Epifanía, monasterio de Santa María de Carracedo (León). Foto: autores.

${ }^{43}$ Gómez-Moreno 1925, p. 413.

${ }^{44}$ Debido a su diámetro, este no pudo servir para una puerta de dimensiones mayores, al poseer tres arquivoltas abocinadas. El tímpano se compone, al menos, por tres piezas, de diferentes materiales. Uno, el granito o arenisca marrón, usado para el Cristo en Majestad, San Lucas y San Marcos y otro, esquisto pizarroso verdoso, con el que se esculpieron las figuras de San Juan y San Mateo. Su estilo nos conduce a momentos más tardíos. El movimiento del ángel Mateo, pero, especialmente, la figura en mandorla, con pliegues angulosos que GómezMoreno relacionó con fórmulas "flamencas", o el rostro sonriente de Cristo, son características que permiten vincular la escultura con otras de los primeros años del siglo XIII. Por ejemplo, presenta similitudes con la figura en mandorla de la clave de la sala octogonal -llamada sala del archivo-, contigua a la Cocina de la Reina, en las dependencias del monasterio. Finalmente, no descartamos que la pieza pudiese haber estado en un lucillo funerario del entorno de la portada, lo cual conduce nuevamente a épocas no tempranas. 


\section{EL ACCESO EN EL MARCO DE LA ESCULTURA DEL REINO DE LEÓN A MEDIADOS DEL SIGLO XII}

En el estudio del románico del antiguo reino de León, la historiografía se centró principalmente en la escultura realizada en torno al año 1100 y sus conexiones con las corrientes del sur de la Galia, y particularmente, el Languedoc. Ello ha relegado a un segundo plano los trabajos que se continuaron haciendo en las principales catedrales del reino a mediados del siglo XII. Mientras las sedes de Zamora, Ciudad Rodrigo y Salamanca han recibido gran atención, las profundas reformas que afectaron a las fábricas románicas en León, Oviedo y Astorga, durante los siglos del gótico, han velado las grandes infraestructuras anteriores ${ }^{45}$.

A las dos líneas que marcó el profesor Moralejo, que diferenciaba aquella corriente escultórica focalizada en la dirección este-oeste y desarrollada desde Silos al Pórtico de la Gloria y la que discurría en la trayectoria norte$\operatorname{sur}^{46}$, desde Carrión a San Vicente de Ávila; se ha sumado otra vía que uniría los trabajos del claustro románico de Oviedo, la escultura de Santa Marta de Tera y la catedral de Astorga. Sin embargo, dentro de este último itinerario, son los escasos restos - pero sobresalientes-, de la desaparecida catedral asturicense, los que merecen mayor atención (fig. 12).

Fue en Astorga y en los años centrales del siglo XII donde se ejecutaron obras de suma importancia, reflejadas por la documentación de entre los años 1150-1160 ${ }^{47}$. Las fuentes y los restos materiales corroboran que, en esas fechas, en la diócesis de Astorga y, factiblemente, en la fachada principal de su catedral, se estaba introduciendo la estatua columna, innovación de los soportes tradicionales conocidos hasta entonces, antes que en otros centros del noroeste hispano.

\footnotetext{
${ }^{45}$ A excepción de los estudios: Ruiz de la Peña 2003, pp. 29-45; Carrero 2003; Cosmen, Herráez, Valdés 2010, pp. 119-132; Rico 2010, pp. 117-150; 2002.

${ }^{46}$ Moralejo 1973, pp. 294-310.

${ }^{47}$ Cosmen, Herráez, Valdés 2010, p. 126.
} 

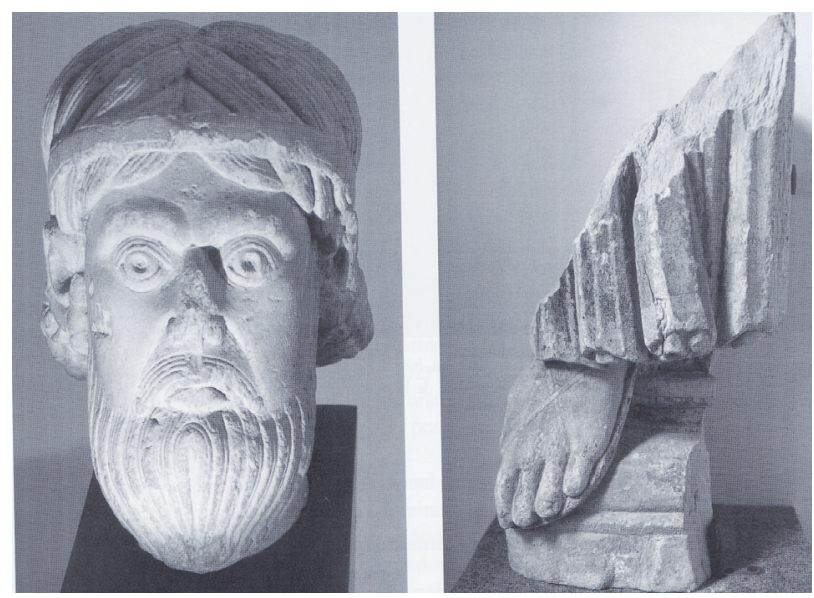

Fig. 12. Fragmentos de una portada, catedral de Santa María de Astorga (León). Foto: Cosmen Alonso.

Esta primicia debe comprenderse en el marco de una tendencia internacionalizante de la escultura hispana, vinculada, para el caso asturicense, con los talleres activos durante la década de los años cuarenta en las portadas de la basílica de Saint-Denis de París. A las características estilísticas comparables con Île-de-France, y que corroboran un horizonte común para los artífices de ambos centros, deben añadirse, ahondado en estas relaciones, las documentadas relaciones entre la casa real leonesa con la monarquía franca.

\section{LA COMITENCIA ARTÍSTICA DE LA CORTE LEONESA}

Entre los años 1150-1157, el rey Alfonso VII ofreció dádivas a las cinco sedes episcopales del reino y a sus principales monasterios. Así, si la promoción regia es indudable, también la nobleza apoyó los trabajos en las canteras abiertas. Tras la muerte del emperador, su sucesor, Fernando II, continuó esta labor de comitencia, beneficiando a las iglesias diocesanas y fomentando las donaciones, primero, a Compostela y luego, a Oviedo y Astorga.

Esta munificencia regia como elemento de dinamización de la actividad artística, se vio más impulsada, si cabe, por la generosidad de las damas de la corte, tal y como ratifican las fuentes escritas. Este factor resulta muy relevante ${ }^{48}$.

\footnotetext{
${ }^{48}$ Ibidem, p. 129.
} 
En lo que respecta a la revolucionaría inclusión de las estatuas columna en las fachadas de los templos legionenses, no debe olvidarse que, en Santa Marta de Tera la presencia de este nuevo soporte se explica, en parte, a partir de la promoción de doña Elvira, hija de Alfonso VI y protectora, junto con su hija Teresa, del cenobio zamorano ${ }^{49}$. No es casualidad que la dama se encontrase también protegiendo a la catedral asturicense durante su construcción.

A partir de Astorga y Zamora, esta temprana adopción de modelos presentes en la basílica de Saint-Denis de París, se asume en los talleres activos en el foco asturicense, transmitiéndose a otros núcleos de producción escultórica secundaria. Sólo un taller maduro y plenamente articulado, de insignes referentes y de alta calidad pudo estar capacitado, a partir de los años 1150-1160, para gestar modelos y ejercer influencia.

En esta secuencia debe enmarcarse la figura de la infanta leonesa doña Constanza $(† 1160)$, hija del emperador y asidua de las rutas que unían Castilla y la Isla de Francia, tal y como revela el periplo que inició en noviembre de 1153, partiendo de Soria y con destino en Orléans, donde se casó con el rey Luis VII (1137-1180) y el arzobispo de Sens la coronó como reina de Francia.

El carácter internacional de las obras que patrocinó refleja la realidad política y artística de los caminos de peregrinación, pues volvió a viajar desde Francia a Compostela en 1154, y regresó al reino paterno algunos meses, entre 1156-1157. La relación con su tía, la infanta Sancha, fue estrecha desde su infancia y ambas habían estado presentes en 1149 durante el acto de consagración de San Isidoro de León ${ }^{50}$. Finalmente, los viajes, bien documentados, se detienen entre 1159 y 1160 , momento de su fallecimiento en Francia. En este contexto, por supuesto, no es descartable la ayuda de la reina para la circulación de artífices y el influjo que debieron ejercer sobre los focos de Astorga y Carracedo. Así se comprende mejor la afirmación de Ambrosio de Morales, quien insistía en el afrancesamiento de los círculos intelectuales frecuentados por Constanza, mencionando la presencia del magister Hugo y el scriptor Giraldus en la adopción de modos francos en la cancillería hispana, muy visible en la documentación de Carracedo y, particularmente, en el privilegio de fundación que es lindo y que tuvo canciller, maestro Hugo, de Francia (...) lo truxo Constanza, que fue francesa ${ }^{51}$.

\footnotetext{
${ }^{49}$ Ibidem, pp. 122-129.

${ }^{50}$ Williams 2011, pp. 413-435.

${ }^{51}$ Morales 1765, pp. 168-169; Carrasco 2012,p. 88, señala a estos dos escribas en el proceso de afrancesamiento.
} 
A su muerte, la dama fue enterrada en Saint-Denis, confirmando su cercanía a la orden benedictina, frente al Císter que regía el monasterio de Barbeau, en Seine-Port, allí donde fue sepultado su marido ${ }^{52}$.

La familiaridad con Francia, desde una perspectiva cultural y artística, se presenta como un factor común a las dos nobles. Por su parte, la infanta Sancha había sido educada por dos maestros francos: el obispo de Segovia, Pedro de Agen y don Bernardo, canónigo de Toledo y después obispo de Zamora, todos ellos del círculo de Bernardo de la Sauvetat y procedentes del sur de Francia ${ }^{53}$. Es muy posible que la joven Constanza fuese criada por la domina del infantado en este ambiente.

Finalmente, el dato más relevante y que atestigua la comparecencia de ambas nobles en la promoción artística lo aporta un documento de 1152 , mediante el que doña Sancha encarga al abad Florencio la fundación de un monasterio femenino, bajo la regla de San Benito, en la heredad de San Miguel de Almázcara (El Bierzo, León). El diploma lo firma también Constanza emperatoris filia $^{54}$. Por lo tanto, era conocedora de primera mano de los intereses de la rehabilitación carracetense y su conversión en un centro relevante.

\section{DIMENSIÓN SIMBÓLICA DE LA PORTADA}

La puerta objeto de estudio conmemora a dos de las figuras más destacadas en la rehabilitación del monasterio desde el año 1138. Por un lado, el rey Alfonso VII, que apoyó la obra que capitaneaba su hermana la infanta Sancha, señora del infantado, con el Bierzo entre sus obligaciones; y por otro lado, el prelado que llevó a cabo el cambio: el abad Florencio.

Las imágenes elegidas se colocaron en el acceso norte a la iglesia, paso abierto al exterior incluso cuando el cuerpo del templo aún estaba en obras. Las efigies unían simbólicamente el poder real -regnum- y el eclesiástico -sacerdotium-. Estas ideas, expuestas públicamente para ser vistas por laicos y religiosos en pleno camino de peregrinación jacobeo, se imbrican en el pensamiento benedictino del siglo XII ${ }^{55}$, reafirmando la aún no adscripción del monasterio de Carracedo a la orden bernarda en estos momentos.

${ }^{52}$ Abella 2015, vol. I, pp. 247-248.

${ }_{53}^{53}$ Martín 2003, p. 158.

${ }^{54}$ Ibidem, doc. 61, pp. 301-302. En el siglo X existió en este lugar un monasterio que Alfonso V confirmó como propiedad de Sampiro. Véase Pérez 1952, p. 439.

${ }^{55}$ La unión explícita de ambos poderes refleja líneas de pensamiento político de la Europa del momento. Por ejemplo, durante la querella de las investiduras de 1111, cuando el emperador Enrique V y el papa Pascual II negociaban con fragor, para ayudarse en sus decisiones, el monarca pidió consejo al abad de Cluny para restablecer la unidad de reino y sacerdocio. Véase Pacaut 1986, pp. 192-193. 
Por otra parte, la imagen del abad no pudo ser planificada por el mismo Florencio, sino por uno de sus sucesores. El abad Diego (1153-1155) estuvo poco tiempo en el cargo pero, según su epitafio, había pasado 18 años bajo la santa Regla y por lo tanto, quince de ellos teniendo a Florencio como $\mathrm{abad}^{56}$. Su cercanía ofrece un marco lógico que refrenda la necesidad de conmemorar el recuerdo mediante la efigie del que había sido reorganizador del monasterio en los tiempos de crisis, cuando fue traído desde Corullón. Diego acompañó al abad durante el proceso de restauración, desde la decisión de erigir un nuevo edificio, la construcción de la cabecera y, posiblemente, hasta cuando se inició el buque del templo.

A la tendencia continuista en las obras retomadas por Didaco, se debe sumar nuevamente el apoyo de los anteriores comitentes: el rey, la infanta Sancha ${ }^{57}$ y la cátedra asturicense, ahora ocupada por Pedro Cristiano, un monje carracetense ${ }^{58}$.

Ante estas redes políticas, no parece improbable que don Diego recurriese al núcleo artístico más activo y potente por entonces. Entre 1150 y 1160 la documentación alude a la obra de Santa María de Astorga ${ }^{59}$. En una de las portadas esculpidas de esta iglesia mayor, como innovación en los territorios hispanos, se introdujo tempranamente el formato de la estatua columna.

Por los datos aportados concluimos que las dos efigies de Carracedo están relacionadas directamente con ese foco artístico de Astorga y que, a su vez, los antecedentes directos se encuentran en la escultura de Saint-Denis. Siendo aún más concretos, relacionamos las esculturas bercianas con el artífice activo en la abacial francesa que ejecutó las cabezas de los patriarcas de la arquivoltas del portal central de la fachada occidental, algunas de ellas hoy conservadas en el Museo del Louvre.

Los especialistas del conjunto francés profundizaron en este escultor secundario ${ }^{60}$, al que llaman Maestro de los Ancianos o de los Patriarcas, caracterizado por formas menos refinadas, de menor calidad técnica y volúmenes escultóricos más pequeños ${ }^{61}$. Estas particularidades se repiten en las

\footnotetext{
${ }^{56}$ García 1997, pp. 201-202.

${ }^{57}$ Hace donación a San Martín de Castañeda, dependiente de Carracedo, de una heredad en Lampreana: Martín 2003, doc. 68, pp. 308-309.

${ }^{58}$ Quintana 1985, pp. 338-348, señala que el abad Diego aparece en 1154 con el obispo Pedro Cristiano, nobles y eclesiásticos. El 9 de diciembre de 1155, Alfonso VII y doña Rica, estando en Burgos, dan a don Diego de Carracedo la villa de Fervenza de Barrio. Pedro Cristiano confirma el documento.

${ }^{59}$ Cosmen, Herráez, Valdés 2010, p. 126.

${ }^{60}$ Crosby, Blum 1973, pp. 209-266, distinguen tres manos escultoras en ese portal.

${ }^{61}$ Sobre el que llaman Maestro Secundario o de los Patriarcas de Saint-Denis, véase Joubert 1990, pp. 83-96.
} 
efigies bercianas, hasta encontrar similitudes absolutas con algunas cabezas de patriarcas del museo parisino ${ }^{62}$ (fig. 13).
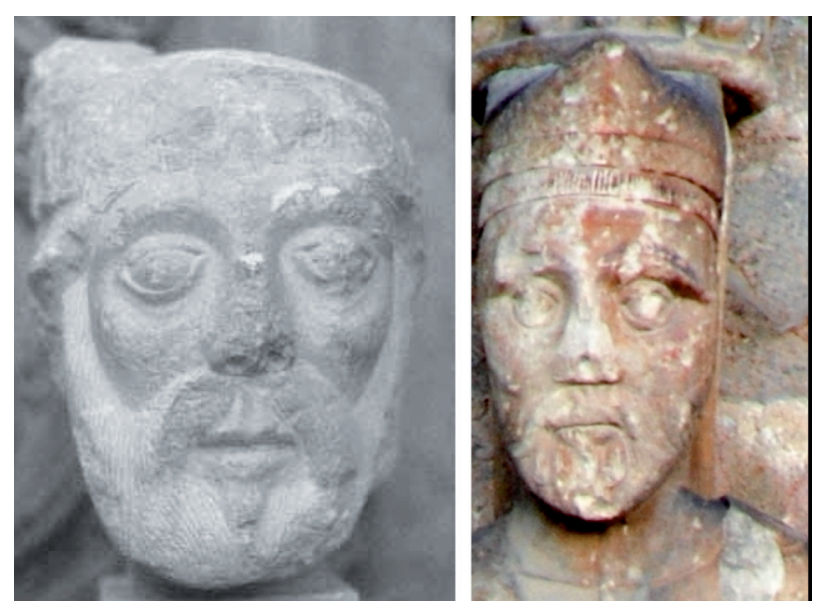

Fig. 13. Cabeza del llamado Maestro de los Patriarcas, basílica de Saint-Denis (París). Foto: Pamela Blunt.

Un maestro conocedor de las experiencias francesas, activo en el foco de Astorga, facturó las esculturas de Carracedo entre 1153 y 1160. El encargo de la fachada lo pudo realizar el abad Diego, marcando con la efigie de Florencio el acceso a la iglesia que este había iniciado, en un lugar, el crucero, que además sellaba el punto donde él mismo habría de retomar las obras. Pero su inesperada muerte y corto mandato llevaron al abad Gualterio a finalizar ese proyecto, siendo ya rey Fernando II (1157-1188).

El conjunto de imágenes conservadas proyectó un mensaje sobre el espectador, pero el ámbito tuvo diferentes audiencias: clérigos más o menos letrados y laicos de diferente o nula preparación. Es difícil reflexionar sobre la dimensión simbólica ante la carencia de inscripciones, que hoy no conser-

\footnotetext{
${ }^{62}$ Las dos cabezas fueron estudiadas por: ibidem, p. 96, fig. 18, procedentes de la tercera arquivolta del pórtico central de Saint-Denis. Véase también Blum 1992, quien analiza la cabeza 53 de la segunda arquivolta derecha, fig. 13a de su estudio. El tratamiento del rostro en la figura del abad Florencio y del patriarca número 53 posee indudables paralelismos: la talla de la nariz, muy triangular, los arcos supraciliares profundos, los ojos almendrados con párpados gruesos bordeando la cuenca del ojo, sin iris marcados - presentes en la cabeza de Astorga-, el rictus y surco subnasal o filtrum señalado en los dos casos. El bigote que rodea la boca y baja, rematando en crenchas con mechones cruzados en la perilla, aparece tanto en la obra parisina como en la de Carracedo. Finalmente, ambas presentan una marcada incisión alrrededor de las mejillas, como perfilando la barba.
} 
vamos pero que bien pudieron estar pintadas, por ejemplo, sobre la filacteria del rey ${ }^{63}$.

En cuanto a la presencia del abad en el acceso de un templo benedictino -desconocida hasta estas fechas entre los restos conservados en el reino de León- cabe apelar a ciertas directrices remarcadas en la misma Regla.

El abad Florencio llegó al monasterio a requerimiento de doña Sancha y el rey Alfonso VII, para refundarlo y encauzarlo, pues gozaba, desde el siglo XI, de horas bajas. Fue elegido por sus méritos de vida ${ }^{64}$, por ser administrador digno (...) y recto ${ }^{65}$. La Regla señala que el abad debe ser íntegro, parco, piadoso antes que severo, prudente, próvido y discreto. Florencio fue elegido para dar nueva vida al viejo monasterio, de ahí su imagen, mitrado y con báculo, símbolo de la aplicación de la norma.

No es casual que se insista en la figura abacial como signo de rectitud, probidad de su comportamiento ${ }^{66}$, recta razón, pues si es un poco más severo es con el fin de corregir los vicios o mantener la caridad ${ }^{67}$. Se insiste aquí en el papel de pastor del rebaño.

Si bien la idea no es genérica, obviamente, de esta fachada, la Regla considera al abad pastor plenamente responsable de todas las deficiencias que el padre de familia encuentre en sus ovejas ${ }^{68}$. No es azaroso que el topos vuelva a reiterarse en la desaparecida lauda sepulcral de Florencio, que insistía en los mismos términos: preclaro y pastor del frágil rebaño.

Por otra parte, el asunto de la caridad aparece en las pautas benedictinas como una de las funciones primordiales de la orden, encargada de atender a los necesitados con generosidad ${ }^{69}$. Este matiz nos parece relevante.

Sobre la cabeza del abad se sitúa un capitel que representa el castigo de la avaricia o el avaro, penado por dos demonios (fig. 6). La figura del prior ejemplifica un discurso general sobre la rectitud, pues este debe dar justicia a la hora de exterminar los pecados mediante la caridad ${ }^{70}$, curar los males de sus costumbres (del rebaño) ${ }^{71}$.

${ }^{63}$ En Santa Marta de Tera, ligada al foco escultórico que gestó las estatuas columna carracetenses, la figura de Judas Tadeo de la actual puerta norte posee una filacteria con inscripción.

${ }^{64}$ Regla, LXIV, 1. Recientemente se adscribieron los restos de la portada a la etapa benedictina: Poza 2016, nota 340, p. 162.

${ }^{65}$ Regla, LXIV, 6.

${ }^{66}$ Regla, I, 29.

${ }^{67}$ Regla, I, 47.

${ }^{68}$ Regla, II, 7.

${ }^{69}$ Panfosky 2004, p. 141: "puesto que la caridad es la virtud mayor de la vida monástica".

${ }^{70}$ Regla, IV, 26.

${ }^{71}$ Regla, II. 
Dos diablos azuzan mediante su horquilla al avaro, con la soga al cuello: el infierno abrasa por sus pecados a los que menosprecian a Dios ${ }^{72}$; insistiendo así en el castigo para aquellos cenobitas que se den a la avaricia y no sean pródigos o malgasten el patrimonio del monasterio ${ }^{73}$. Se persigue, en definitiva, la peste de la avaricia ${ }^{74}$, uno de los vicios más castigados por la Regla, que condena el vicio de la propiedad ${ }^{75}$. La fuente personifica este pecado a través de Ananías y Safira ${ }^{76}$.

Por lo tanto, el capitel resulta una imagen ejemplificante que, al exhibirse en una fachada, proyecta el castigo que cause miedo a los demás ${ }^{77}$. El abad vela tanto por la impartición de justicia como por la ostentación pública del castigo pues no disimula culpas de delincuentes ${ }^{78}$. Todo ello se concreta en la esquina de la cesta del capitel donde se muestra la figura de un clérigo con hábito ${ }^{79}$, del que surgen garras de ave y el cuerpo plumífero se remata en alas desplegadas.

Finalmente, se completa el mensaje con otra figura masculina, posiblemente tonsurada y vestida que, parece, está desenvainando una espada.

Esta narración esculpida, por sus medidas, la disposición de las escenas y las similares soluciones técnicas empleadas, continuaría en el capitel siguiente, donde se muestra al mismo hombre con la espada ya en alto. Sin solución de continuidad nos conduce a la escena adyacente donde una figura humana, caída en tierra, recibe el ataque de un felino que con sus zarpas atrapa su cabeza (fig. 8). Tal y como se dice en la Regla: por ti andamos continuamente amenazados del cuchillo y tratados como reses de degüello. Pensamos que esta fuente, leída en el monasterio continuamente ${ }^{80}$, aunque si bien no dicta en forma de texto aquello que el artífice trasladó a la piedra, si permite comprender el ideario general del ciclo, que gira siempre en torno a la condena del pecado de la avaricia.

Haciendo pareja con el abad Florencio se presenta la efigie del monarca Alfonso VII, personificando el otro poder fáctico del monasterio, el regio ${ }^{81}$.

\footnotetext{
${ }^{72}$ Regla, VII, 11.

${ }^{73}$ Regla, XXXI, 12.

${ }^{74}$ Regla, LVII.

${ }^{75}$ Regla, LV, 18.

${ }^{76}$ Regla, LVII, 5.

${ }^{77}$ Regla, XLVIII.

${ }^{78}$ Regla, II, 26.

${ }^{79}$ Resta, muy fragmentaria, la cabeza del clérigo, del que aún es perceptible su cabello tonsurado y la oreja.

${ }^{80}$ La Regla concreta el tiempo de lectura durante el verano y el invierno. Por otra parte, según Jerónimo Llamas se conservaba en Carracedo este texto, con anotaciones, lo que da idea de su uso cotidiano.

${ }^{81}$ Llamas insistía en que la iglesia era de patrocinio real y que había sido ocupada irregularmente por los nobles.
} 
El limes de entrada al templo se protege y sella por la estirpe real, fundadora y patrocinadora del enclave, bien a través del apoyo del monarca, bien a través de su hermana Sancha, y continuado por Fernando II. Estando presente la imagen de su padre se ratifica la impronta real de la obra, pues ya hemos indicado que Fernando II confirmó las propiedades de su progenitor y su protección a Carracedo. La comparecencia aquí del abad y el rey, en forma monumental, no fue frecuente en las portadas románicas del antiguo reino de León, y menos en una cronología tan temprana. Sin duda existe una intencionalidad propagandística, ideada por Diego y, más seguramente, materializada por Gualterio durante los primeros años de su mandato, en la que se buscó rememorar los personajes más notables en la historia de la abadía, remarcando los poderes que la sustentaron e insistiendo en los ideales benedictinos. Ni en la basílica regia del reino, San Isidoro, las tres portadas esculpidas albergaron, que sepamos, a los comitentes ${ }^{82}$. Se trata de un unicum en toda la iconografía escultórica hispana ligada a este rey, exceptuando su presencia en la sigilografía.

La cronología que hemos dado a estas esculturas viene apoyada por las experiencias plásticas datadas entre 1138 y 1146, precisamente cuando los paleógrafos ubican la introducción de la imagen del monarca en los sellos, en el marco de una cancillería de progenie francesa. Aunque nosotros no hayamos relación alguna, ya Sandoval elucubró sobre la posibilidad de que los sellos de los privilegios reales dados por el monarca a Carracedo -y que también vio Ambrosio de Morales- hubieran sido la base sobre la que los escultores crearon esta imagen, afirmando los eruditos decimonónicos que el monarca mostraba el privilegio de fundación del monasterio en la filacteria ${ }^{83}$.

Alfonso VII representa aquí la largueza benefactora del rey que, desde los inicios, y a través también de Sancha, protegió el cenobio, pero también encarna la benevolencia del hijo, Fernando II, que conmemora las buenas obras de su progenitor. No es casual que sea precisamente en los tres capiteles ubicados en la columnata izquierda, como describió el padre Llamas en el siglo XVI, donde se ubicó el capitel de la Epifanía. El ciclo se constituye a partir de la confrontación de dos extremos simbólicos. La avaritia, el avaro y su castigo y la largitas, la generosidad y munificencia de los Magos, que entregan sus dones.

La caridad, no obstante, es una idea estereotipada entre los relatos de la escultura románica del siglo XII, y está igualmente muy presente en la

\footnotetext{
${ }^{82}$ La imagen más relevante es la de Fernando I en las pinturas del panteón isidoriano. Por otra parte, en la catedral de Compostela se representó al rey Alfonso VI y al obispo Diego Peláez en sendos capiteles, pero las funciones de estas imágenes son diferentes a la proyección pública que poseen las estatuas bercianas.

${ }^{83}$ Menéndez 1998, vol. 1, p. 109.
} 
Regla ${ }^{84}$. Estuvo tan asimilada en este contexto que hasta llegó a convertirse en una fórmula bien explotada en el encabezamiento del documento fundacional de Sancha, que reitera las ideas de caridad, pobreza y limosna como dones enfrentados al pecado ${ }^{85}$.

La Edad Media conoció estos discursos a partir de los textos de Prudencio, quien dedicó un capítulo de la Psicomaquía a reflexionar precisamente sobre la avaritia y la largitas $^{86}$. Finalmente, fueron más tarde los autores de mediados de siglo XII los que, buscando una alegoría de este último don, la materializaron a partir de los Reyes Magos, marcados por su realeza y generosidad $^{87}$, entendidos como los primeros peregrinos y, por lo tanto, tema habitual en las ruta de peregrinación a Santiago de Compostela ${ }^{88}$.

La dicotomía entre la avaricia, sus castigos y la salvación mediante la limosna encuentra referentes en iglesias románicas hispanas y francesas ${ }^{89}$. Más allá de estas, el ciclo esculpido en el tímpano de SaintBertrand-de-Comminges resulta un buen modelo para comprender el discurso figurativo de Carracedo. En el tímpano del acceso principal se esculpió la escena de la entrega de los dones por los Magos al Niño, validando el acto el patrón del templo, San Bertrán, que se presenta vestido de canónigo y con el báculo ${ }^{90}$. No es casual que un capitel doble de la columna izquierda acoja la figura del avaro azuzado por tres seres demoníacos, que mediante unas horquillas similares a las que asen los diablos de Carracedo, castigan al condenado.

Finalmente, para corroborar las líneas rectoras del ciclo carracetense, consideramos coherente relacionar el mensaje expuesto en la fachada perdida con las estatuas columna realizadas para la sala capitular de la abadía de SaintGeorges de Boscherville (Seine-Maritime), y que, desde el siglo XIX, los estudiosos vincularon con el ideal benedictino y los textos de la Regla. Este

\footnotetext{
${ }^{84}$ Regla, II, 22.

${ }^{85}$ Sobre la fórmula documental véase Martín 2003, p. 246.

${ }^{86}$ Prudencio, Obras, eds. Ortega y Rodríguez 1981, pp. 305-361. Sobre la iconografía del avaro: Vila-Belda 2016, pp. 34-43.

${ }^{87}$ Pedro de Blois, The Later, ed. Revell 1993, carta 31, pp. 160-164.

${ }^{88}$ Desde su presencia en la portada del Perdón de Villafranca del Bierzo y, en ciclos más extensos, como en el coro pétreo de Mateo.

${ }^{89}$ Se ha contextualizado el capitel del avaro, con el saco de monedas y el diablo en la iglesia palentina de San Isidoro de Dueñas dentro de la llamada "iconografía benedictina". A finales del siglo XI aparece el avaro, con la soga y la bolsa, castigado por dos demonios, en la Porte des Comptes de Saint-Sernin de Tolouse. En estos ambientes monásticos y formando parte de un conjunto de capiteles en el que de nuevo aparece la Epifanía, cabe mencionar el avaro de San Martín de Frómista. Sobre San Martín simbolizando la caritas frente a los demonios: Gómez, Asiáin 1995. Sobre el carácter benedictino de estos temas: Poza 2011, pp. 251-279.

${ }^{90}$ Garland 1994, p. 111; Pilloix 2016, vol. I, pp. 28-43.
} 
conjunto fue datado en tercer cuarto del siglo XII y, estilísticamente, también se ligó con la escultura de Saint-Denis (fig. 14).

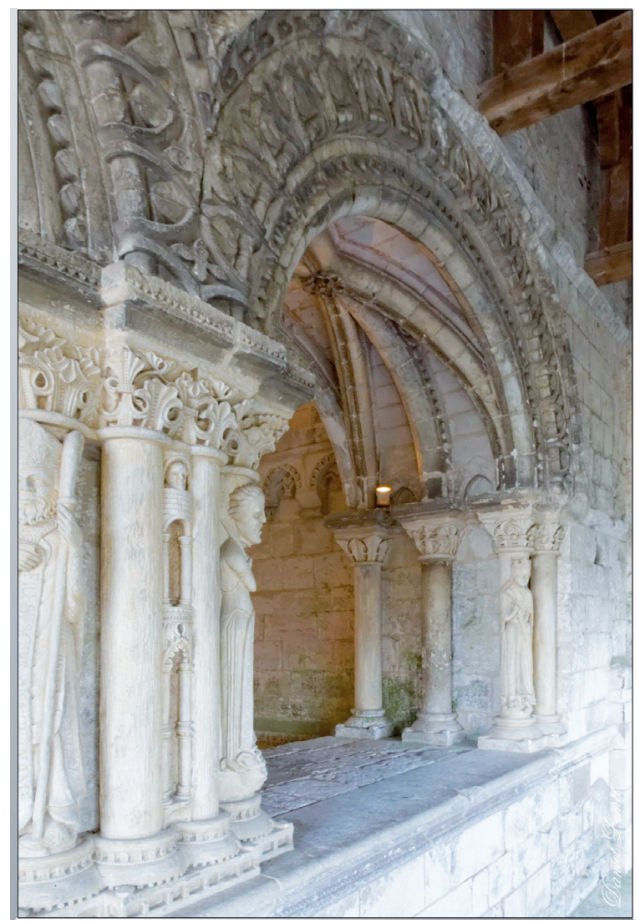

Fig. 14. Portada de la sala capitular de la abadía de Saint-Georges, Boscherville (Seine-Maritime). Foto: Daniel Lemel.

El acceso a este recinto se abre con la figura de un abad que, como en Carracedo, representa la imagen de la imposición y custodia del cumplimiento riguroso de la Regla. En este caso no existe duda alguna sobre su función figurativa pues su significado se articula con la inscripción de la filacteria, donde se lee: FILI SUSCIPE DISCIPLINAM ${ }^{91}$. Otra de las estatuas columna anexas presenta una posible imagen femenina, aunque el deterioro que sufrieron las esculturas provocó daños irreparables en los rostros. Con todo, el elemento que nos interesa destacar reside en el epígrafe que muestra, donde se lee: EGO

\footnotetext{
${ }^{91}$ El conjunto fue abordado por los autores decimonónicos antes del restauro que reparó los daños de las revueltas calvinistas de 1562. Véanse los dibujos de Deville 1827, p. 35, quien identifica la escultura con el primer abad del monasterio, Luis o con su sucesor Víctor. Son más recientes: Pressouyre 1968, p. 151; Morrison 1993, pp. 46-50; Maho 1995, pp. 129-142; Lescroart 2000, pp. 341-347.
} 
MORS HOMINEM JUGULO CORRIPIO, identificada como la imagen de la muerte, vestida con hábito femenino. Posee dos cuchillos sobre su vestimenta, mientras otro se lo lleva a la garganta. La cabellera, incluso antes del restauro, se concibió encrespada (fig. 15).


Fig. 15. Efigie femenina y efigie del abad, portada de la sala capitular de la abadía de Saint-Georges, Boscherville (Seine-Maritime). Foto: Daniel Lemel.

Frente al pecado y el castigo que llevan a la muerte, corregidos por la rectitud del abad, habrá de alcanzarse la bienaventuranza. La tercera filacteria la porta una efigie femenina, coronada y cuya cartela indica: VITA BEATA $\operatorname{VOCOR}^{92}$.

Del mismo modo que había ocurrido, tempranamente, en la órbita de influencia de la escultura de Saint-Denis y los ejemplos franceses mencionados, la puerta se convirtió en Carracedo en un espacio privilegiado para la exposición de imágenes referenciales para el pensamiento benedictino ${ }^{93}$. En el caso berciano fue, además, un lugar conveniente para enmarcar visualmente los enterramientos que, durante siglos, se ubicaron en sus aledaños.

La desparecida puerta que hemos analizado albergó soluciones técnicas e iconográficas desconocidas en los territorios del noreste hispano entre

${ }^{92}$ La figura portaba un cetro, según indicó Deville. Existían además otras estatuas hoy perdidas. Remitimos a los dibujos de J.N.C. 1838. Las iniciales utilizadas corresponden al nombre y apellidos del autor. Al tratarse de una publicación minoritaria y del siglo XIX no hemos podido localizar la identidad completa del estudioso.

${ }^{93}$ Roux 2004, p. 846; Bango 1992, García 2018, vol. 5, pp. 305-330. 
los años 1150 y 1160, incomprensibles sin la comparecencia del patronazgo de la corte legionense y las relaciones políticas y artísticas con la Isla de Francia. Es ahí donde reside su notabilidad.

\section{BIBLIOGRAFÍA CITADA}

Abella Villar, Pablo (2015), Patronazgo regio castellano y vida monástica femenina: morfogénesis arquitectónica y organización funcional del monasterio cisterciense de Santa María la Real de las Huelgas de Burgos (ca. 1187-1350), vol. I, Gerona, Universidad de Gerona (tesis doctoral inédita).

Alonso Álvarez, Raquel (2007), Los promotores de la orden del Císter en los reinos de Castilla y León: familias aristocráticas y damas nobles, "Anuario de Estudios Medievales" 37/2, pp. 653-710.

Aranguren, Iñaki (2000), La Regla de San Benito, Madrid, Biblioteca de Autores Cristianos.

Balboa, José Antonio (1997), El Monasterio de Carracedo, León, Diputación Provincial de León.

Bango Torviso, Isidro (1992), El espacio para enterramientos privilegiados en la arquitectura medieval española, "Anuario del Departamento de Historia y Teoría del Arte" 4, pp. 93-132.

Blanco, Rogelio; Díaz-Jiménez, Eloy (1989), Jovellanos y León, León, Instituto Leonés de Cultura.

Blum, Pamela (1992), Early Gothic Saint-Denis: Restorations and Survivals, Berkeley, University of California Press.

Carderera y Solano, Valentín (1855-1864), Iconografía española: colección de retratos, estatuas, mausoleos, vol. I, Madrid, Imprenta Campuzano.

Carrasco Lazareno, María Teresa (2012), El sello real en Castilla: tipos y usos del sellado en la legislación y en la práctica documental (siglos XII al XV), en Galende Díaz, Juan Carlos (coord.), De sellos y blasones: miscelánea científica, Madrid, Asociación de Diplomados en Genealogía, Heráldica y Nobiliaria, pp. 63-170.

Carrero Santamaría, Eduardo (2003), El conjunto catedralicio de Oviedo en la Edad Media. Arquitectura, Topografia y Funciones en la Ciudad Episcopal, Oviedo, Real Instituto de Estudios Asturianos.

Cavero Domínguez, Gregoria (1994), Catálogo del monasterio de San Miguel de las Dueñas, León, Universidad de León.

Cavero Domínguez, Gregoria (2007). El esplendor del cister en León siglos XII-XIII, León, Fundación Hullera Vasco-Leonesa. 
Cavero Domínguez, Gregoria (2013), Sancha Raimúndez: an Infanta in the Exercise of her Power, "Imago temporis. Medium Aevum" 7, pp. 271-297.

Cosmen Alonso, María Concepción (1989), El arte románico en León: diócesis de Astorga, León, Universidad de León.

Cosmen Alonso, María Concepción (2012), El arte del císter en la provincia de León hasta 1250, en El císter en el reino de León. Exposición Monasterio de Santa María de Carracedo, León, Instituto Leonés de Cultura, pp. 61-80.

Cosmen Alonso, María Concepción; Herráez Ortega, María Victoria; Valdés Fernández, Manuel (2010), La escultura monumental tardorrománica en el reino de León. Evolución e innovaciones introducidas por los círculos cortesanos a mediados del siglo XII, en Rückert, Claudia; Staebel, Jochen (eds.), Mittelalterliche Bauskulptur in Frankreich und Spanien: Im Spannungsfeld des Chartreser Königsportals und des Pórtico de la Gloria in Santiago de Compostela, Frankfurt am Main, Vervuert, pp. 119-132.

Crosby, Summer; Blum, Pamela (1973), Le portail central de la façade occidentale de Saint-Denis, "Bulletin Monumental" 3/131, pp. 209266.

Deville, Achille (1827), Essai historique et descriptif sur l'église de l'abbaye de Saint-Georges, Rouen, De l'Imprimerie de Nicétas Périaux jeune.

Fernández Catón, José María (1990), Colección de documentos del archivo de la catedral de León (1109-1187), vol. V, León, Centro de Estudios e Investigación San Isidoro.

Flórez, Enrique (1762), España Sagrada, vol. XVI, Madrid, Gabriel Ramírez.

García Calles, Luisa (1972), Doña Sancha, hermana del Emperador, León, Centro de Estudios e Investigación San Isidoro - Barcelona, CSIC.

García González, Sonsoles (2018), Reappropiated Antiquity in the Funerary of the Kingdom of León and Castile in the High Middle Ages, en Tomaini, Thea (ed.), Dealing With The Dead: Mortality and Community in Medieval and Early Modern, Leiden-Boston, Brill, vol. 5, pp. 305-330.

García Lobo, Vicente (1996), Monasterio de Santa María de Carracedo. Museo, León, Instituto Leonés de Cultura.

García Lobo, Vicente (1997), De epigrafía cisterciense: las inscripciones del monasterio de Carracedo, "Cistercium: Revista cisterciense" 208, pp. 189-206. 
Garland, Emmanuel (1994), L'Adoration des Mages dans l'art roman pyrénéen, "Les Cahiers de Saint-Michel de Cuxa. Marie, l'art et la société des origines du culte au XII ${ }^{\text {ème }}$ siècle" 25, pp. 99-120.

Gómez Gómez, Agustín; Asiáin Yárnoz, Miguel Ángel (1995), Caritas et diabolus en la iconografía de San Martín: el caso de San Martín de Unx (Navarra), "Príncipe de Viana" 205, pp. 285-310.

Gómez-Moreno, Manuel (1925), Catálogo monumental de España. Provincia de León: (1906-1908), vol. I, Madrid, Ministerio de Instrucción Pública y Bellas Artes.

González García, Miguel Ángel (1990), Aportaciones a la historia de la actual iglesia monasterial de Carracedo, "Bierzo" 12, pp. 211-218.

González, Julio (1943), Regesta de Fernando II, Madrid, Instituto Jerónimo Zurita.

J.N.C. Mediaeval Sculpture, “The Gentleman's Magazine" 9 (enero-junio) 1838, pp. 364-366.

Joubert, Fabienne (1990), La tête de Moïse du portail sud de la façade occidentale de Saint-Denis, "Monuments et Mémoires" 71, pp. 83-96.

Jovellanos, Gaspar Melchor de (1915), Diarios: (memorias intimas): 17901801, Gijón, Instituto de Jovellanos.

Lescroart, Yves (2000), Deux chapiteaux du cloître roman de l'abbaye SaintGeorges-de-Boscherville, "Bulletin Monumental" 158/4, pp. 341347.

Llamas, Jerónimo (1593), Fundación y dotación del Monasterio de Carracedo según el Manuscrito de Fray Jerónimo de Llamas (1593), Ponferrada, Fundación Ana Torres Vilariño [reed. 1996].

Maho, Jacques Le (1995), Autour de la fondation de l'abbaye de Boscherville (début du XII ${ }^{e}$ s.). Quelques observations historiques et archéologiques, "Bulletin de la commission départementale des Antiquités de la Seine-Maritime" 43, pp. 129-142.

Martín López, Encarnación (2003), Colección documental de la infanta Doña Sancha (118-1159). Estudio crítico, en León y su historia. Miscelánea histórica VIII, León, Fuentes y Estudios de Historia Leonesa.

Martínez Martínez, Martín (1997), Cartulario de Santa María de Carracedo: 992-1500, Ponferrada, Instituto de Estudios Bercianos.

Menéndez Pidal de Navascués, Faustino (1998), Los sellos de Alfonso VII, en Soto Rábanos, José María (ed.), Pensamiento medieval hispano: homenaje a Horacio Santiago-Otero, Madrid, CSIC, vol. 1, pp. 99116.

Miguel Hernández, Fernando (1996), Monasterios leoneses en la Edad Media: Palat de Rey y Carracedo en ArqueoLeón. Historia de León a 
través de la Arqueología. Ciclo de conferencias. Actas, León, Junta de Castilla y León, pp. 131-162.

Moralejo Álvarez, Serafín (1973), Esculturas compostelanas del último tercio del siglo XII, "Cuadernos de Estudios Gallegos" 28, pp. 294-310.

Morales, Ambrosio de (1765), Viage de Ambrosio de Morales por orden del Rey D. Phelipe II a los Reynos de León, Galicia y Asturias, Madrid, Antonio Marín.

Morrison, Kathryn (1993), The Figural Capitals of the Chapterhouse of SaintGeorges- de-Boscherville, "British archaeological association conference transactions: medieval art, architecture and archaeology at Rouen" 12 , pp. 46-50

O’Neill, John (2017). Privilegio expedido por Alfonso VII, rey de Castilla y León (1104-1157), en Codding, Mitchell (ed.), Tesoros de la Hispanic Society. Visiones del Mundo Hispánico, Madrid, Museo Nacional del Prado, pp. 128-129.

Pacaut, Marcel (1986), L’Ordre de Cluny. 909-1789, París, Fayard.

Panfosky, Erwin (2004), El abad Suger sobre la abadia de Saint-Denis y sus tesoros artísticos, Madrid, Cátedra.

Pedro de Blois (1993), The Later Letters of Peter of Blois (Auctores Britannici Medii Aevi, XIII), ed. Elizabeth Revell, Oxford, Oxford University Press.

Pérez de Urbel, Justo (1952), Sampiro. Su crónica y la monarquía leonesa en el siglo $X$, Madrid, CSIC.

Pilloix, Oriane (2016), Les parties romanes de l'ancienne cathédrale SainteMarie de Saint-Bertrand-de-Comminges (Haute-Garonne), vol. I, Tolosa, Université Toulouse Jean Jaurès (Mémoire de Master 2. Études Médiévales sous la direction de Quitterie Cazes).

Poza Yagüe, Marta (2011), Las portadas de los prioratos cluniacenses de Tierra de Campos en tiempos de Alfonso VI: una iconografía de corte monástico para una manifestación pública", "Anales de Historia del Arte, Volumen Extraordinario" 2, pp. 251-279.

Poza Yagüe, Marta (2016), Portadas románicas de Castilla y León. Formas, imágenes y significados, Aguilar de Campoo, Fundación Santa María la Real.

Pressouyre, León (1968), Deux inscriptions ravennates, et le cloître de SaintVital, "Bulletin de la Société nationale des Antiquaires de France" s.n., pp. 140-154.

Prieto, Emilio José (1916), Datos para la historia del monasterio de Carracedo, Carracedo, s. n. (fotocopia del manuscrito original Instituto de Estudios Bercianos).

Prudencio, Aurelio Clemente (1981), Obras Completas, eds. Alfonso Ortega, Isidoro Rodríguez, Madrid, Editorial Católica. 
Quadrado, José María (1855), Recuerdos y bellezas de España. Provincia de León, Madrid, Joaquín Verdaguer.

Quintana, Augusto (1968), El Obispado de Astorga en los siglos IX y X, Astorga, Publicaciones del Archivo Diocesano.

Quintana, Augusto (1977), El Obispado de Astorga en el siglo XI, Astorga, Publicaciones del Archivo Diocesano.

Quintana, Augusto (1983), Temas bercianos: los monasterios del Bierzo Bajo, vol. II, Ponferrada, Bérgida.

Quintana, Augusto (1985), El Obispado de Astorga en el siglo XII, Astorga, Publicaciones del Archivo Diocesano.

Recuero Astray, Manuel (1979), Alfonso VII, Emperador. El imperio hispánico en el siglo XII, León, Centro de Estudios e Investigación San Isidoro.

Recuero Astray, Manuel (1998), Documentos medievales del reino de Galicia. Alfonso VII (116-1157), A Coruña, Xunta de Galicia.

Rico Camps, Daniel (2002), El románico de San Vicente de Ávila (estructuras, imágenes, funciones), Murcia, Nausícaä.

Rico Camps, Daniel (2010), Los maestros de Carrión de los Condes y San Vicente de Ávila: reflexiones sobre la decantación hispana de la escultura borgoñona, en Huerta Huerta, Pedro Luis (coord.), Maestros del románico en el Camino de Santiago, Aguilar de Campoo, Fundación Santa María la Real, pp. 117-150.

Rodríguez, Justiniano (1995), La monarquía leonesa, de García I a Vermudo III (910-1037), en El Reino de León en la Alta Edad Media, III. La monarquía astur-leonesa. De Pelayo a Alfonso VI (718-1109), León, Centro de Estudios e Investigación San Isidoro, pp. 37-64.

Roux, Caroline (2004), Entre sacré et profane. Essai sur la symbolique et les fonctions du portail d'église en France entre le XIe et le XIII' siècle, "Revue belge de Philologie et d'Histoire" 82/4, pp. 839-854.

Ruiz Asencio, José Manuel (1987), Colección documental del Archivo de la Catedral de León (986-1031), vol. III, León, Centro de Estudios e Investigación San Isidoro.

Ruiz de la Peña González, Isabel (2003), La reforma románica de la Cámara Santa de la Catedral de Oviedo en el contexto del patrocinio artístico de Fernando II, "De Arte" 2, pp. 29-45.

Sandoval, Prudencio de (1792), Historia de los reyes de castilla y León, vol. II, Madrid, Cano.

Vila-Belda Martí, Faustina (2016), Imagen y palabra. Los pecados más frecuentes en la iconografía de Castilla Medieval, (siglos XI al $X V$ ), Madrid, Universidad Autónoma de Madrid (tesis doctoral inédita). 
Williams, John (2011), Fernando I and Alfonso VI as Patrons of the Arts, "Anales de Historia del Arte, Volumen Extraordinario" 2, pp. 413435.

Yepes, Antonio de (1615), Coronica General de la Orden de San Benito, vol. V, Valladolid, Francisco Fernández de Córdoba.

Fecha de recepción del artículo: enero 2019

Fecha de aceptación y versión final: septiembre 2019 